\title{
Modifications of bull spermatozoa induced by three extenders: Biociphos, low density lipoprotein and Triladyl, before, during and after freezing and thawing
}

\author{
Lamia Amirat, Marc Anton, Daniel Tainturier, Gérard Chatagnon, Isabelle Battut and \\ Jean Luc Courtens ${ }^{2}$ \\ Laboratoire des Biotechnologies et Pathologies de la Reproduction, Ecole Nationale Vétérinaire de Nantes, \\ BP 40706, 44307 Nantes, France, ${ }^{1}$ Groupe Physico-Chimie des Emulsions, Laboratoire d'Etude des Interactions des \\ Molécules Alimentaires, INRA, BP 71627, 44316 Nantes cedex 3, France and ${ }^{2}$ INRA, Physiologie de la \\ Reproduction et des comportements, Nouzilly, 37380 France
}

Correspondence should be addressed to M Anton; Email: anton@nantes.inra.fr

\begin{abstract}
The success of artificial insemination with frozen semen implies the reduction of the deleterious effects on the cells induced by this technique. These effects can occur as early as during the first dilution in an extender, as well as at any step, during or after the freezing process.

In this work, we have compared the modifications induced by Triladyl, low density lipoproteins (LDL) and Biociphos extenders, after dilution and cooling to $4{ }^{\circ} \mathrm{C}$ for 1,4 and $24 \mathrm{~h}$. Alterations in the cell structures were visualized by electron microscopy (EM). More than $80 \%$ of spermatozoa were injured after incubation for $4 \mathrm{~h}$ in Triladyl, while $3 \%$ and $47 \%$ were counted in LDL and Biociphos respectively. This latter extender was deleterious to cell membrane integrity after incubation for $4 \mathrm{~h}$ or longer.

The ultrastructure of frozen spermatozoa was studied by EM of cryofixed-cryosubstituted samples obtained from regular $0.5 \mathrm{ml}$ French straws frozen using our usual protocol. The main differences between samples concerned the size and appearance of the frozen extender veins, while very few cell defects were found to be added by the freezing process at any depth in the straws.

After thawing, semen motility was twofold higher $(P<0.05)$ in Biociphos $(64 \%)$ and LDL $(61 \%)$ than in Triladyl $(32 \%)$ and the cells were less altered in LDL. We concluded that the LDL extender offers a better protection for storage of frozen spermatozoa, and can probably also be used for the preservation of fresh semen for short periods.

Reproduction (2005) 129 535-543
\end{abstract}

\section{Introduction}

While homogenized whole milk, fresh or reconstituted skimmed milk, or coconut milk have been proposed for the preservation of semen, egg yolk is still commonly used for cryopreservation of bovine spermatozoa in France. Among the extenders, Triladyl or Optidyl are quite popular, despite the fact that, because of the addition of fresh egg yolk, they have variable compositions. Their use has been encouraged, thanks to the excellent protection that they provide for bull spermatozoa (Polge \& Rowson 1952).

However, this protection is counterbalanced to some extent by known limitations. Egg yolk introduces possible sanitary risks (Ahmad \& Foote 1986, Bousseau et al. 1998, Van Wagtendonk-de Leeuw et al. 2000, Vishwanath \& Shannon 2000) and several egg yolk components interfere with laboratory biochemical assays and metabolic investigations (Wall \& Foote 1999). Furthermore, some studies (Kampshmidt et al. 1953, Pace \& Graham 1974, Watson \& Martin 1975) have shown that these extenders can reduce the respiration and motility of spermatozoa.

For these reasons, many professionals are waiting for substitutes with defined compositions, to at least limit the risks cited above and maintain a high protection of the cells. Among the diverse possibilities, Pace \& Graham (1974) purified egg yolk extracts, some of which, such as the low density lipoprotein (LDL) fraction, seemed promising. Their results were confirmed by many investigators (Foulkes 1977, Quinn \& Chow 1980, Demianowicz \& Strezek 1996, Moussa et al. 2002). However, the nature of the protection is still a matter for debate. Since LDLs are the main component of the widely used egg yolk, and 
because today's technology allows for easy and reasonably safe extraction, we have started a series of experiments to acquire a better knowledge of the events occurring during sperm preservation, and to devise a good extender with a controlled composition.

Several criteria are thus necessary. The extender for cryopreservation should contain a source of energy used naturally by the cells, such as fructose. It should contain enough salts, to balance osmolarity before freezing and avoid high salt concentrations in order to prevent cell injury. In fact, the initial concentrations in the extender will increase by up to 6.25 times during the freezing process (Courtens \& Réty 2001).

In addition, the extender should display $\mathrm{pH}$ buffer capacity, have viscous properties appropriate to the chosen freezing protocol and, at least for the bull, it should contain a permeable non-toxic cryoprotectant with high membrane permeability. This necessity led us to propose an extender hereafter referred to as LDL. In the present work, we first compared the ultrastructure of bull spermatozoa after incubation for $1-24 \mathrm{~h}$ at $4{ }^{\circ} \mathrm{C}$ in one extender containing egg yolk, Triladyl, one containing LDL and one containing another commercial subtitute for egg yolk (Biociphos). Secondly, ultrastructural observations of cryofixed and cryosubstituted straws were used to compare the eventual effects during the freezing process. This method (cryosubstitution-cryofixation) consists of a slow replacement of the ice by a solvent (cryosubstitution) concurrent with chemical fixation at a low temperature $\left(-80^{\circ} \mathrm{C}\right)$ of the spermatozoa without thawing the sample (cryofixation). The solvent contains a fixative, $\mathrm{OsO}_{4}$, the role of which is to fix the cells as soon as they are released from solid phase during the cryosubstitution process. Finally, the viability of spermatozoa after thawing was assessed by motility measurement.

\section{Materials and Methods \\ Semen collection and processing}

Semen samples used in this experiment were obtained from three Prim Holsteins bulls from the National Veterinary School of Nantes; the bulls were 2, 4 and 5 years old respectively. Four ejaculates were obtained from each bull using artificial vaginas. The semen samples were assessed for volume, sperm concentration, percentage of motile spermatozoa and quality of movement.

Semen was then divided into three equal fractions; the first one was diluted with Biociphos (IMV, L'Aigle, France), an extender containing soybean lecithin extract. The second one was LDL extender containing $2.42 \mathrm{~g}$ Tris, $1.48 \mathrm{~g}$ citric acid, $1.00 \mathrm{~g}$ fructose, $6.4 \mathrm{ml}$ glycerol, $25 \mathrm{mg}$ gentamicine, $50000 \mathrm{IU}$ penicillin and $8 \%$ dry matter LDL (LDL was extracted and used at $8 \%$ (dry matter), which is the optimum concentration in bull semen extender found by Moussa et al. (2002)), made up to $100 \mathrm{ml}$ with sterile non-pyrogenic water. The third fraction was diluted with
Triladyl (Minitüb, Tiefenbach, Germany); it differs from the second extender only in one component as it contains $20 \%(\mathrm{w} / \mathrm{v})$ egg yolk instead of $8 \% \mathrm{LDL}$. The osmolalities of the extenders were measured with a freezing point depression osmometer (micro-osmometre type 13/13 DR auto cal; Hermann Roebling, Berlin, Germany). They were 1283, 1367 and $1372 \mathrm{mOs} / \mathrm{kg} \mathrm{H} \mathrm{H}_{2} \mathrm{O}$ for Biociphos, LDL and Triladyl extenders respectively.

The diluted semen was divided into two aliquots as follows. Aliquot 1, fresh semen; the diluted semen was stored at $+4{ }^{\circ} \mathrm{C}$ for 1,4 and $24 \mathrm{~h}$ before fixation in $1 \%$ glutaraldehyde in $0.175 \mathrm{M}$ cacodylate/ $\mathrm{HCl}$ buffer, $\mathrm{pH} 7.2$. The fixative solution was carefully added to semen $(4: 1)$ and stored at $4{ }^{\circ} \mathrm{C}$ until further processing. For each bull, a fraction of undiluted ejaculate was similarly fixed as control. Aliquot 2, frozen semen; after dilution, a concentration of $120 \times 10^{6}$ spermatozoa/ml was obtained. Semen was cooled from 37 to $4{ }^{\circ} \mathrm{C}$ for $1.5 \mathrm{~h}$. Polyvinyl chloride (PVC) straws $(0.25 \mathrm{ml}$ and $0.5 \mathrm{ml}$; IMV) were filled and maintained at $4{ }^{\circ} \mathrm{C}$ for $2 \mathrm{~h}$. They were then frozen for $10 \mathrm{~min}$ $\left(-120^{\circ} \mathrm{C}\right)$ above nitrogen gas before being immersed into liquid nitrogen $\left(-196^{\circ} \mathrm{C}\right)$ and stored. Straws containing $0.5 \mathrm{ml}$ were used for electron microscopy (EM) because it was extremely difficult to recover enough material from straws with a lower diameter. However, the motility of cells (see below) was measured from spermatozoa frozen and thawed in $0.25 \mathrm{ml}$ straws using the same freezing protocol.

\section{Electron microscopy}

\section{Fresh samples}

After three washes in cacodylate buffer, using $900 \mathrm{~g}$ centrifugations and resuspensions, spermatozoa were post-fixed in $1 \%$ osmium tetroxyde in $0.175 \mathrm{M}$ cacodylate/ $\mathrm{HCl}$ buffer for $1 \mathrm{~h}$ at $20^{\circ} \mathrm{C}$ and washed four times in distilled water. Following dehydration in a water/alcohol series, from 50 to $100 \%$ ethanol, they were impregnated with 1-3-epoxypropane for $20 \mathrm{~min}$ and embedded in EPON 812 (Serva, Heidelberg, Germany).

\section{Frozen samples}

The frozen straws were cut into $5 \mathrm{~mm}$ stick-shaped pieces under liquid $\mathrm{N}_{2}\left(-196^{\circ} \mathrm{C}\right)$ and placed for cryofixation and cryosubstitution in $2 \%$ osmium tetroxyde $\left(\mathrm{OsO}_{4}\right)$ in acetone for 3 days at $-80^{\circ} \mathrm{C}$. After gentle rewarming to $20^{\circ} \mathrm{C}$, they were washed in acetone. The plastic containers were discarded, and the material was rehydrated in an acetone/water series, up to $50 \%$. This procedure was used in order to solubilize the crystallized sugars present in the extender. After a further dehydration in an acetone/water series, the pieces were embedded in EPON 812. The small cylindrical pieces were orientated in plastic blocks to be cut perpendicular to the main straw axes. This allowed the cutting of thin sections passing through the frozen material located from the periphery to the centre of the straws. 


\section{Observations}

Thin sections mounted on 200 mesh grids were stained with uranyl acetate $(4 \%$ in water) for $30 \mathrm{~min}$ and put in citrate buffer $(0.1 \%$ in $0.1 \mathrm{M} \mathrm{NaOH})$ for $5 \mathrm{~min}$ at $20^{\circ} \mathrm{C}$. They were observed with a Phillips CM10 EM (Eindhoven, The Netherlands). At least 1000 sections through the spermatozoa were observed in each sample to record the percentages of intact spermatozoa and the defects affecting the incubated cells (ruptured plasma membranes, acrosome reactions (AR), lysis and enlargements). The location of the freeze-substituted cells in the depth of the straws was recorded, taking into account that the bar spacing of the EM grids was equal to $0.1 \mathrm{~mm}$.

\section{Automated analysis of frozen and thawed semen motility}

Sperm motility was assessed with the ATS 20 (J C Distribution International, La Ferté Fresnel, France), a computerized-assisted sperm analysis system with a framing rate set to 20 images per s. This software allows discrimination between the various types of trajectories. A $20 \mu \mathrm{m}$ depth cell vision counting chamber was used. For each extender, three straws were thawed separately by immersion in a water bath at $37^{\circ} \mathrm{C}$ for $45 \mathrm{~s}$. The thawed samples were then transferred into $1 \mathrm{ml}$ plastic tubes and incubated at $37^{\circ} \mathrm{C}$ for $10 \mathrm{~min}$. Five microlitres of each straw were examined and five fields were randomly chosen; $100-150$ trajectories were analysed for their motility (\% of motile spermatozoa), curvilinear line velocity (VCL; $\mu \mathrm{m} / \mathrm{s})$, straight line velocity (VSL; $\mu \mathrm{m} / \mathrm{s})$, linearity index (LIN) $(\mathrm{LIN}=\mathrm{VSL} / \mathrm{VLL} \times 100)$, amplitude of the lateral head displacement $(\mathrm{ALH} ; \mu \mathrm{m})$ and velocity of the average path (VAP; $\mu \mathrm{m} / \mathrm{s})$.

Unless otherwise stated in the text, all chemicals were purchased from Sigma-Aldrich chimie, St Quentin Fallavier, France.

\section{Statistical analysis}

The results are expressed as means \pm S.E.M. The statistical significances of the effect of the extenders on the motility of frozen and thawed semen and on alterations in spermatozoa after 1, 4 and $24 \mathrm{~h}$ of incubation with both extenders were determined by analysis of variance using the Bonferroni method. Populations displaying $P$ values $<0.05$ were considered as significantly different.

\section{Results}

\section{Integrity of spermatozoa - incubation of fresh spermatozoa in the three extenders}

Triladyl

After $1 \mathrm{~h}$, all plasma membranes over the sperm heads were covered with dense granules also present in the surrounding egg yolk. In sections passing through the anterior part of the heads, $46 \%$ of spermatozoa were intact, $18 \%$ of plasma membranes were ruptured and $36 \%$ of acrosomes were reacted or lysed (Fig. 1a and Table 1).
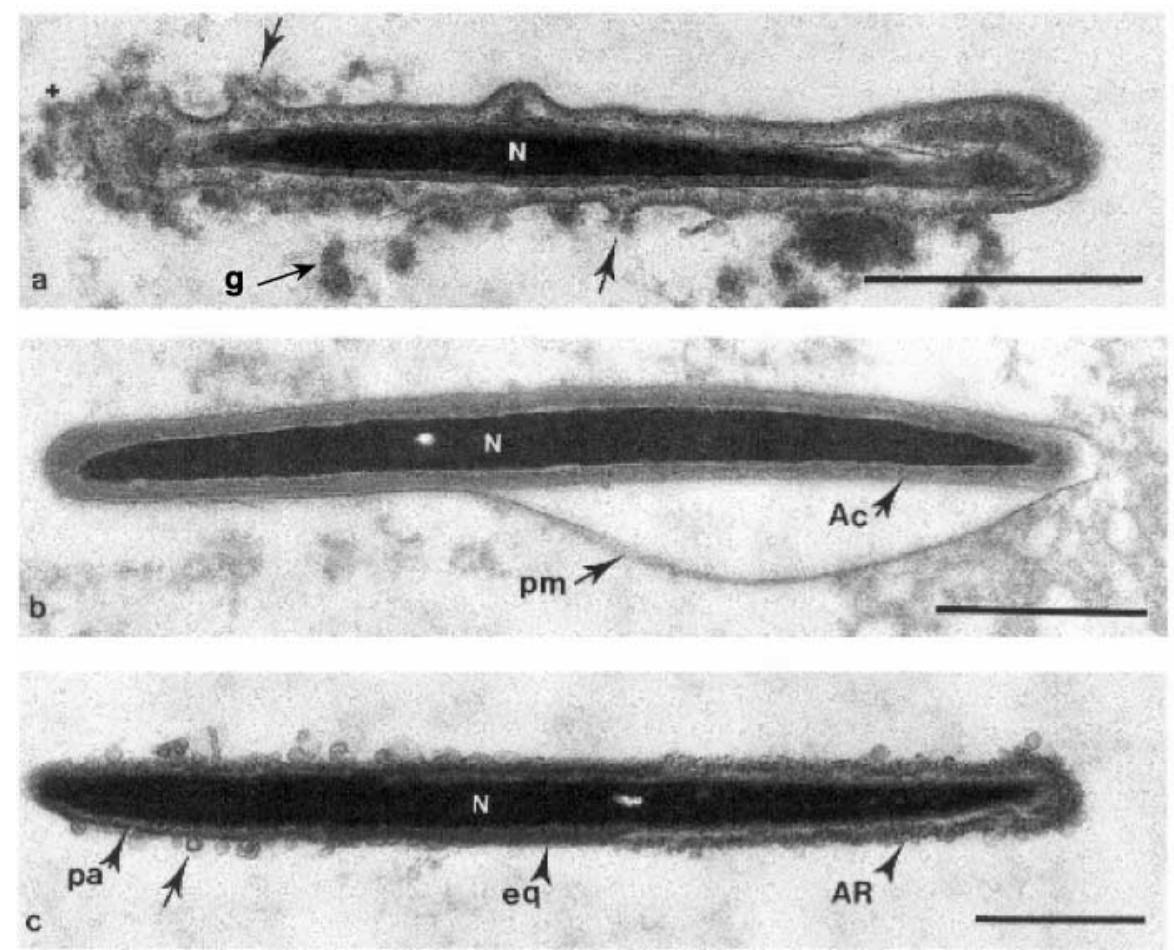

www.reproduction-online.org
Figure 1 Sperm heads after contact with the extender for $1 \mathrm{~h}$. Bars $=1 \mu \mathrm{m}$. (a) Triladyl ( $\times 41$ 800). N, nucleus; g, granules; with fuzzy contours; arrows, ruptures. (b) LDL ( $\times 31$ 400). pm, plasma membrane; Ac, acrosomal content. (c) Biociphos $(\times 24300)$. $\mathrm{Pa}$, post-acrosomal lamina; arrow, blebs; eq, equatorial segment, $A R$, acrosome reaction. 
Table 1 Comparison between cell alterations after 1, 4 or $24 \mathrm{~h}$ of incubation in Biociphos, LDL and Triladyl extenders at $4^{\circ} \mathrm{C}$

\begin{tabular}{|c|c|c|c|c|c|c|c|c|c|c|}
\hline & \multirow[b]{2}{*}{ Control } & \multicolumn{3}{|c|}{$1 \mathrm{~h}$} & \multicolumn{3}{|c|}{$4 \mathrm{~h}$} & \multicolumn{3}{|c|}{$24 \mathrm{~h}$} \\
\hline & & Triladyl & LDL & Biociphos & Triladyl & LDL & Biociphos & Triladyl & LDL & Biociphos \\
\hline$\%$ Ruptured PM & 0.30 & $18.05^{\mathrm{a}}$ & $0.28^{\mathrm{b}}$ & $0.28^{\mathrm{b}}$ & $42.96^{\mathrm{a}}$ & $0.29^{\mathrm{b}}$ & $0.57^{\mathrm{b}}$ & $51.64^{\mathrm{a}}$ & $0.97^{\mathrm{b}}$ & $39.50^{\mathrm{c}}$ \\
\hline$\%$ True AR & 0.45 & $28.06^{\mathrm{a}}$ & $0.47^{b}$ & $10.90^{\mathrm{b}}$ & $17.45^{\mathrm{a}}$ & $0.96^{\mathrm{b}}$ & $36.98^{\mathrm{c}}$ & $16.78^{\mathrm{a}}$ & $2.51^{\mathrm{b}}$ & $0.95^{\mathrm{b}}$ \\
\hline$\%$ Acrosome lysis & 0.15 & $8.04^{\mathrm{a}}$ & $0.09^{b}$ & $0.28^{\mathrm{b}}$ & $27.99^{a}$ & $2.02^{\mathrm{b}}$ & $15.57^{\mathrm{c}}$ & $26.62^{\mathrm{a}}$ & $2.32^{\mathrm{b}}$ & $36.64^{\mathrm{c}}$ \\
\hline$\%$ Acrosome AR + lysis & 0.61 & $36.10^{\mathrm{a}}$ & $0.56^{\mathrm{b}}$ & $11.18^{\mathrm{b}}$ & $45.44^{\mathrm{a}}$ & $2.99^{\mathrm{b}}$ & $52.55^{\mathrm{c}}$ & $43.39^{\mathrm{a}}$ & $4.84^{\mathrm{b}}$ & $37.60^{\mathrm{c}}$ \\
\hline$\%$ Acrosome enlargement & 0.00 & $0.00^{\mathrm{a}}$ & $0.09^{\mathrm{a}}$ & $0.19^{\mathrm{a}}$ & $0.00^{\mathrm{a}}$ & $7.03^{\mathrm{b}}$ & $0.00^{\mathrm{a}}$ & $0.00^{\mathrm{a}}$ & $30.95^{\mathrm{b}}$ & $0.00^{\mathrm{a}}$ \\
\hline$\%$ Intact & 99.09 & $45.84^{\mathrm{a}}$ & $99.07^{b}$ & $88.34^{\mathrm{b}}$ & $11.60^{\mathrm{a}}$ & $89.69^{b}$ & $46.89^{c}$ & $4.97^{\mathrm{a}}$ & $63.25^{b}$ & $22.90^{\mathrm{C}}$ \\
\hline$n$ (observations) & 661 & 1119 & 1075 & 1055 & 1129 & 1038 & 1060 & 1067 & 1034 & 1048 \\
\hline
\end{tabular}

For each incubation period $(1,4$ or $24 \mathrm{~h}$ duration) significant differences $(P<0.05)$ between extenders are denoted by superscript letters. PM, plasma membranes; control, freshly ejaculated semen.

After $4 \mathrm{~h}$, only $11.6 \%$ of cells were intact. Alterations already present after $1 \mathrm{~h}$ were enhanced, and more than $42 \%$ of plasma membranes were disrupted and $45 \%$ of acrosomes were reacted or lysed in all samples (Fig. 2a and Table 1). Granules were also present along the mid and principal pieces.

After $24 \mathrm{~h}$, alterations were enhanced (Fig. $3 \mathrm{a}$ and Table 1 ) as only $5 \%$ of spermatozoa were intact, $52 \%$ of plasma membranes were ruptured and $43 \%$ of acrosomes were reacted or lysed.

\section{$L D L$}

After $1 \mathrm{~h}$, the ultrastructure of the spermatozoa was clearly preserved (Fig. $1 \mathrm{~b}$ and Table 1). The plasma membranes were detached from the underlying cell structures observed in the sperm head, as if they had been subjected to mild hypo-osmotic conditions but ruptures were very exceptional $(0.3 \%)$. No significant modification of acrosomes could be detected (Table 1) and we noted that alterations of spermatozoa after $1 \mathrm{~h}$ of incubation with $\mathrm{LDL}$ at $4{ }^{\circ} \mathrm{C}$ were identical to those observed in the fresh control.

After $4 \mathrm{~h}$, less than $1 \%$ of the cells displayed true ARs and less than $2 \%$ displayed autolysis of their acrosome while enlargement of the acrosomal cap, without noticeable dilution of the acrosomal content, was observed in $7 \%$ of the cells (Fig. $2 \mathrm{~b}$ ). The plasma membranes were unmodified and $89.7 \%$ of cells were intact (Table 1 ).

After $24 \mathrm{~h}, 31 \%$ of cells had a swollen acrosome (Fig. 3b) while very few displayed plasma membrane ruptures $(0.97 \%)$. Moreover, $63 \%$ of spermatozoa remained intact.

\section{Biociphos}

After $1 \mathrm{~h}$, the aspect of the spermatozoa did not differ widely from that observed prior to incubation. Very few cell defects were present. However, many plasma membranes displayed extremely small blebs (Fig. 1c) and true

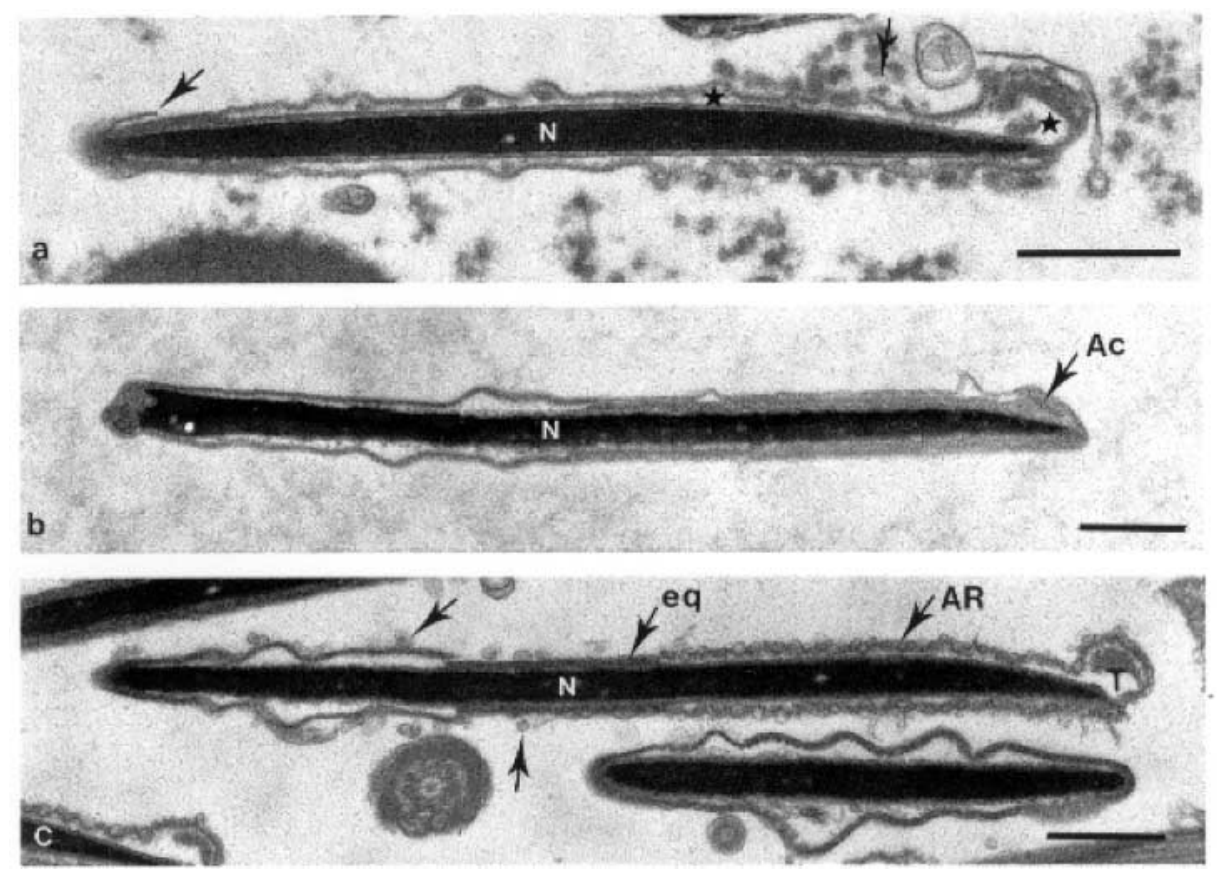

Figure 2 Sperm heads after contact with the extender for $4 \mathrm{~h}$. Bars $=1$ $\mu \mathrm{m}$. (a) Triladyl ( $\times 23$ 000). N, nucleus; star, disappearance of acrosomal content; arrows, ruptured plasma membrane. (b) LDL $(\times 14560)$. Ac, acrosomal content. (c) Biociphos ( $\times 17330)$. eq, equatorial segment; $T$, anterior marginal thickening; arrows, small bubbles along the plasma membrane, AR, acrosome reaction. 


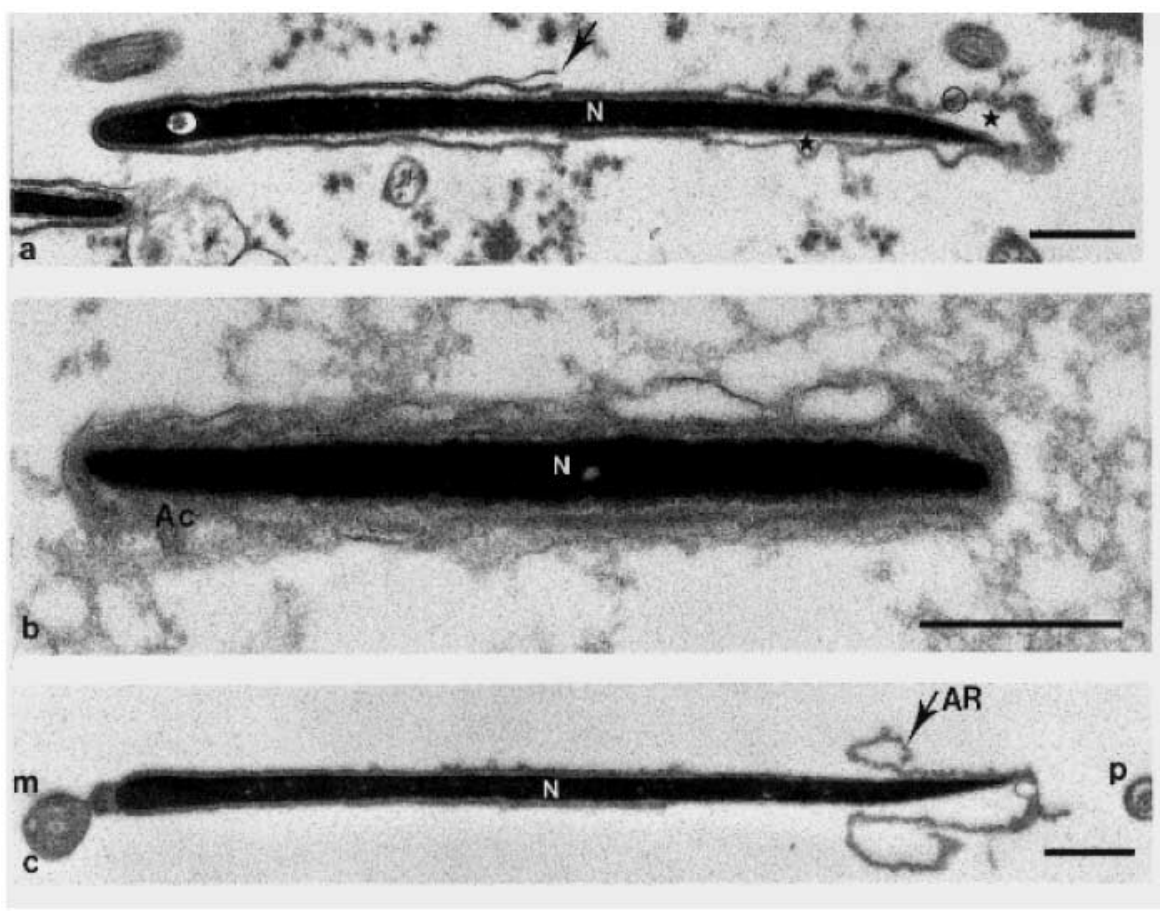

Figure 3 Sperm heads after contact with the extender for $24 \mathrm{~h}$. Bars $=1 \mu \mathrm{m}$. (a) Triladyl $(\times 14750)$. N, nucleus; arrow, ruptured plasma membrane; star, disappearance of acrosomal content. (b) LDL $(\times 29120)$. Ac, acrosomal content. (c) Biociphos $(\times 13120)$. $M$, mid piece; $p$, principal piece, $A R$, acrosome reaction.
ARs (11\%), i.e. with vesiculization of the outer acrosomal cap membrane and overlying plasma membranes, were counted (Table 1).

After $4 \mathrm{~h}, 47 \%$ of cells were unaltered (Table 1 ). Among the altered cells, $37 \%$ of interpretable sections displayed true ARs (Fig. 2c) and the others displayed lysis of the acrosome contents without visible ruptures of the plasma membranes in most sections. Blebs and clear vesicles were still present over the plasma membrane of sperm heads.

After $24 \mathrm{~h}$, while $23 \%$ of cells were intact, $40 \%$ of spermatozoa had no visible plasma membrane (Fig. 3c and Table 1).

\section{Comparison between extenders}

After $1 \mathrm{~h}$, about $46 \%$ of spermatozoa were intact with Triladyl while, with LDL and Biociphos, the majority of cells were intact. Furthermore, no significant differences were observed between them. A highest percentage of acrosome lesions (ARs and lysis) was observed after incubation with Triladyl in comparison with LDL and Biociphos.

We noticed that the percentage of acrosomal lesions was superior with Biociphos as compared with LDL.

After $4 \mathrm{~h}$, the highest percentage of intact cells was observed with LDL (89.7\%) in comparison with Triladyl (11.6\%) and Biociphos (46.9\%). With Triladyl, $43 \%$ of spermatozoa displayed ruptured plasma membranes. Acrosome lesions were essentially observed with Biociphos and Triladyl.

After $24 \mathrm{~h}$, the highest percentage of intact spermatozoa $(63.2 \%)$ was observed with LDL extender, whereas only $23 \%$ and $5 \%$ were intact with Biociphos and Triladyl respectively. At time of incubation, about $40 \%$ of membranes were disrupted whereas with LDL plasma membranes remained intact.

\section{Freeze-substituted spermatozoa}

Because of the protocol used, large $(0.5 \mathrm{ml})$ straws frozen using a protocol adapted for fine $(0.25 \mathrm{ml})$ straws, the ultrastructure of spermatozoa located at different depths cannot be related to the viability of cells thawed from thin straws. However, it was interesting to compare the relative repetitions of ice and of the eutectic phase with the three extenders.

\section{Triladyl}

Low magnifications The extender appeared to be extremely dark after staining. The thickness of the layers was homogeneous and was sufficient to embed all spermatozoa. No difference in ice granulometry was evident at different depths in the straws. The extender was not homogeneous. It contained granules of various sizes and shapes embedded in a lighter material containing very small ice crystals. The latter were more numerous in the centre of the straws (Fig. 4a).

High magnifications Spermatozoa located close to the straw centre contained numerous ice crystals. Most acrosomes in that part were totally iced, displaying a white unstained content. More peripherally, cells were moderately to extremely dehydrated. The frontier between iced cells in the centre and dehydrated cells at the periphery was narrow and located some $0.3 \mathrm{~mm}$ away from the 

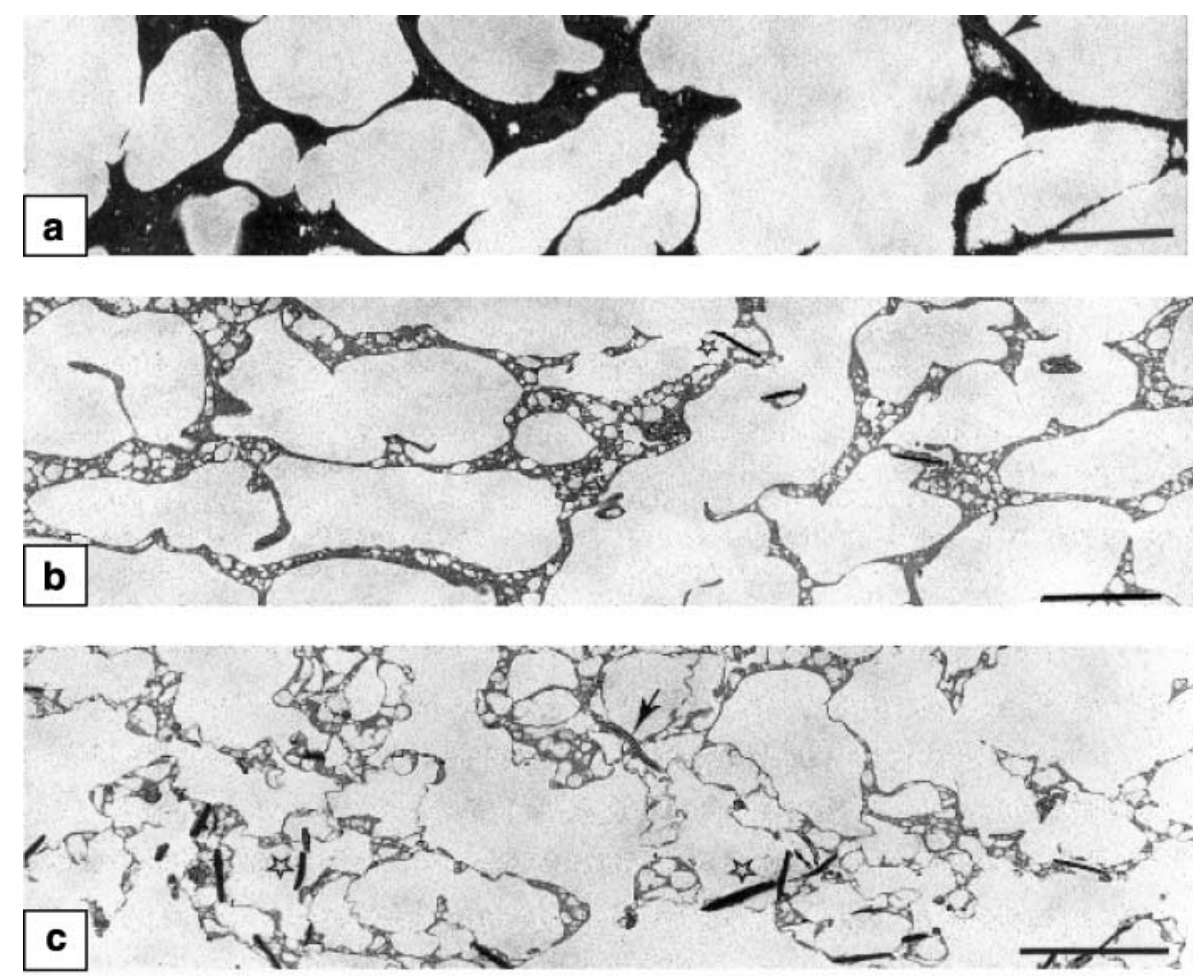

Figure 4 Low magnifications through freeze-substituted straws. Section through the external part of the straw. Bars $=10 \mu \mathrm{m}$. (a) Triladyl $(\times 1900)$. Arrow, dehydrated spermatozoa. (b) LDL $(\times 1700)$. Star, partly embedded cells. (c) Biociphos $(\times 2100)$. Stars, sperm heads not totally embedded in the extender; arrows, flagella filled with ice.

periphery. All cell defects observed after incubation of fresh spermatozoa for $1 \mathrm{~h}$ were present.

\section{$L D L$}

Low magnifications Ice crystals were small in the straw centres. The frozen extender layers were homogeneous and well stained. However, the thickness was not sufficient to totally embed all the cells. Some spermatozoa were partly embedded in ice or separated from ice by an extremely thin layer of extender (Fig. 4b).

High magnifications Cells located close to the centre of the straws displayed mixed intracellular ice contents: when embedded in the extender, the flagella contained large amounts of ice while, when embedded in ice, they were extremely dehydrated.

The cells located more peripherally displayed less intracellular ice content, and the crystals were often very small. However, a mixed situation still occurred according to the cell embedment. The acrosome and the plasma membranes were normal in all cells observed.

\section{Biociphos}

Low magnifications The relative distributions of ice/eutectic phases did not differ widely from those obtained with LDL. The eutectic phase was composed of extremely thin layers of the extender located around spherical large ice crystals. These latter were smaller in the centre of the straws. The frozen extender displayed a very homogeneous light grey staining and, whatever the depth in the straws, it did not totally surround the cells. Many spermatozoa were thus partially embedded both in ice and in the extender (Fig. 4c).

High magnifications Intracellular ice crystals were observed in all flagella located close to the centre of the straws. They filled the mitochondria as well as the axonemes. Cell defects already observed in fresh fractions incubated for $1 \mathrm{~h}$, such as the loss of acrosomes or ruptures of plasma membrane, were present. The spermatozoa located between the straw periphery and $0.2 \mathrm{~mm}$ away contained few intracellular ice crystals. However, the cell parts embedded in ice, i.e. not protected by the extender, were extremely dehydrated. Cells located more centrally displayed ice contents incompatible with life.

\section{Semen motility}

The motility, VSL and VAP (movement characteristics) were significantly higher in semen frozen in $8 \% \mathrm{LDL}$ extender as compared with semen frozen in Triladyl but no difference was observed for VCL and LIN. No significant difference was observed on the motility of frozen semen between the LDL extender and Biociphos. A significant difference occurred between the motilities of semen frozen with Triladyl and Biociphos (Table 2). 
Table 2 Comparison between the movement characteristics of bull spermatozoa after the freeze-thaw process according to the extender used. Values are means \pm S.E.M. of 12 ejaculates (four ejaculates $\times$ three bulls).

\begin{tabular}{lrrr}
\hline & Triladyl & \multicolumn{1}{c}{ LDL } & Biociphos \\
\hline Motility $(1 \%)$ & $31.8 \pm 1.2^{\mathrm{b}}$ & $61.00 \pm 1.5^{\mathrm{a}}$ & $64.1 \pm 1.7^{\mathrm{a}}$ \\
VCL $(\mu \mathrm{m} / \mathrm{s})$ & $49.3 \pm 1.3^{\mathrm{a}}$ & $53.0 \pm 0.8^{\mathrm{a}}$ & $42.7 \pm 1.3^{\mathrm{b}}$ \\
VSL $(\mu \mathrm{m} / \mathrm{s})$ & $31.1 \pm 0.9^{\mathrm{b}}$ & $35.2 \pm 0.5^{\mathrm{a}}$ & $31.6 \pm 0.8^{\mathrm{b}}$ \\
LIN $(\%)$ & $64.0 \pm 1.0^{\mathrm{a}}$ & $66.5 \pm 0.9^{\mathrm{a}}$ & $73.7 \pm 0.8^{\mathrm{b}}$ \\
ALH $(\mu \mathrm{m})$ & $1.3 \pm 0.1^{\mathrm{a}}$ & $1.3 \pm 0.0^{\mathrm{a}}$ & $0.9 \pm 0.0^{\mathrm{b}}$ \\
VAP $(\mu \mathrm{m} / \mathrm{s})$ & $39.4 \pm 1.1^{\mathrm{b}}$ & $44.33 \pm 1.7^{\mathrm{a}}$ & $38.0 \pm 1.0^{\mathrm{b}}$ \\
\hline
\end{tabular}

$P<0.05$ as shown by superscript letter.

\section{Discussion}

The extender containing egg yolk:Triladyl, was more deleterious for bull spermatozoa than with Biociphos or LDL. The alterations in cells occurred during the dilution, prior to the freezing, and the motilities after thawing were largely depressed.

A better survival was observed when Biociphos or LDL were used. Both extenders were relatively non-toxic to cells during incubations for $1 \mathrm{~h}$ while acrosome and plasma membrane alterations occurred after $4 \mathrm{~h}$ in Biociphos. The LDL extender offers better protection to cell structures after incubations up to $24 \mathrm{~h}$, suggesting that it could be a good candidate for semen storage at $4{ }^{\circ} \mathrm{C}$.

The freezing process did not add any alterations in relation to the composition of the extender. However, EM revealed that the widths of the extender layers were not large enough to totally protect the cells from contact with ice, either with the commercial Biociphos or with the LDL extenders.

\section{Triladyl}

The deleterious effect of egg yolk on the cell structures was unexpected as egg yolk has been proven and has been claimed to be an excellent extender for bull sperm for many years (Phillips 1939, Lasley et al. 1942, Bogart \& Mayer 1950), and most authors have focussed their attention on other extender components. However, Pace \& Graham (1974) have shown that fractions extracted from egg provide various levels of protection during the freezethawing process. LDL extracts were supposed to be protective, while HDL were considered to be toxic. However, the toxicity was observed after thawing and the real action could be related either to true toxicity to cells or to modifications of the physical properties of the extender (Courtens \& Réty 2001). In particular, a high viscosity of the extender limits the diffusion of small molecules and ions, from the eutectic phase emerging around growing ice crystals, towards the liquid phase. This limits the differences in concentrations through the depth of the straws. Using HDL in a mineral extender should facilitate the diffusion of small solutes, salts and sugars towards the less concentrated zones in the straws. The HDL, composed of large granules, probably cannot provide a strong resistance to the surrounding diffusion flow. On the other hand, the LDL or other viscous components of the egg yolk effectively limit the flow. Our results do not allow us to chose between these hypotheses, since we did not carry out experiments on freezing with HDL. However, we have demonstrated that some egg yolk components, not contained in the LDL fraction, are toxic for cells prior to freezing. The EM clearly indicated that granular components of the egg yolk were rapidly adsorbed by the plasma membranes, first on the sperm heads and later on the flagella. The nature of the adsorbed granules was not tested here. Following their adsorption, the acrosomes were modified with two patterns: true AR, with vesiculization of portions of the outer acrosome membrane covering the acrosome cap and the overlying plasma membrane, and self destruction of the acrosome, without visible rupture of the plasma membranes. Thirty to eighty percent of cells exhibited destroyed acrosomes after $1 \mathrm{~h}$ in Triladyl, thus reducing the number of viable cells prior to freezing. The high variability observed between samples suggests that contact for $1 \mathrm{~h}$ could be the starting point for the rapid modification of acrosomes. The results were more homogeneous latter. Acrosomal destructions could result from intrusion of $\mathrm{Ca}^{2+}$, which is present in high concentrations in egg yolk (Handbook of Chemistry and Physics 1990) and rapidly enters the cells when the temperature is below $30^{\circ} \mathrm{C}$ (Courtens et al. 1989). The next event, a massive destruction of plasma membranes, leaving less than $20 \%$ of cells intact after $24 \mathrm{~h}$, can be compared to that observed after adding milk lipases to goat spermatozoa (Courtens et al. 1984). Freezing spermatozoa in Triladyl did not produce any unexpected results. The cells located at the periphery of the straws were generally very dehydrated, while those located in the centre were filled with intracellular ice. These observations are common in similar freezing protocols for spermatozoa of different mammals (Courtens \& Réty 2001).

A loss of mobile spermatozoa (close to 50\% loss) is common after freezing bull semen. In this study, a higher percentage of mobile cells was obtained after freezing in LDL extender as compared with semen frozen and thawed in Triladyl. Our repeatable results are in accordance with those obtained by Moussa et al. (2002). Only 31.8\% of spermatozoa were motile after freezing in Triladyl. This could result largely from cell injuries already present prior to freezing.

\section{$L D L$}

LDL was far less aggressive to cells incubated for up to $4 \mathrm{~h}$, a duration compatible with most classical freezing protocols. No alterations of the plasma membranes were observed, and no or very few true ARs occurred. Only $7 \%$ of cells displayed enlarged acrosomes without diffuse acrosomal content after $4 \mathrm{~h}$. They might correspond to dead cells starting autolysis. This pattern was still true 
after contact with LDL for $24 \mathrm{~h}$, but more plasma membrane damage and autolysis of acrosomes was present, leaving $63 \%$ of cells intact. In the frozen state, the organic part of the extender, mostly LDL, formed layers of insufficient thickness to protect the spermatozoa from contact with large ice crystals. Cells embedded partly in LDL and partly in ice displayed the expected patterns: strongly dehydrated in ice, while normally hydrated or dehydrated in $\mathrm{LDL}$, according to the location of the cells in the straws. Larger layers could probably be obtained with an extender containing more $\mathrm{LDL}$ and these extenders could add more protection, but a previous study (Moussa et al. 2002) has shown a significant decrease in semen motility when LDL was used at a high percentage in the extender. However, our observations were made in straws larger than those used in field conditions and, because of differences in heat transfer in small and large straws, it is possible that the relative fractions of pure ice crystals and the surrounding layers of the extender differ in straws of different sizes.

The motility obtained after thawing was much better than that obtained with Triladyl. This is probably largely attributable to the good preservation of living cells prior to freezing.

\section{Biociphos}

Biociphos was also less aggressive to spermatozoa than Triladyl. But in contrast to LDL, more AR were observed early, $11 \%$ after $1 \mathrm{~h}$, growing to $37 \%$ after $4 \mathrm{~h}$. The plasma membranes were also rapidly altered. They displayed a fuzzy appearance after $4 \mathrm{~h}$. Few plasma membranes were intact after $24 \mathrm{~h}$ when only $23 \%$ of cells appeared to be unaltered. The frozen state was not different in Biociphos and in LDL. Layers of frozen extenders were also too tiny to protect all spermatozoa from contact with large ice crystals.

Since motilities obtained with Biociphos did not differ from those obtained with $\mathrm{LDL}$, these extenders allowed increased cell survival after thawing when compared with Triladyl in the conditions used here. These motility results are in accordance with those obtained by Gil et al. (2000), Moussa et al. (2002) and Amirat et al. (2004) and are in opposition to those obtained by Van Wagtendonk-de Leuw et al. (2000). These latter authors observed a higher percentage of motilities with Triladyl than with Biociphos but motility was subjectively estimated and the presence of granules in Triladyl impeded the counting of dead cells. The three extenders can be considered as toxic to cells when they are in contact for 1 day or less for Triladyl and Biociphos. However, the types of cell damage induced by each extender were distinct from each other. A true aggression of cell membranes was observed with Triladyl, and seems to be linked to the presence of small granules affixed to the plasma membranes, while it was retarded in Biociphos. This latter could act as a mild solvent for lipids, since effective plasma membrane ruptures were common after $4 \mathrm{~h}$ and even worse after $24 \mathrm{~h}$. LDL was less toxic to cells after $24 \mathrm{~h}$, since $63 \%$ of spermatozoa were morphogenically intact. In this study we have clearly demonstrated that the LDL extender offers a better protection to cells before freezing. We can connect this result with those obtained with in vitro fertility (Amirat et al. 2004). Actually, in vitro bull semen fertility was maintained after using LDL extender. Furthermore, the cleavage rate was significantly higher after fertilization with semen frozen in LDL as compared with an egg yolk extender (Optidyl). LDL extender could largely replace egg yolk in extenders for bull semen freezing and could be considered for bull semen storage at $4{ }^{\circ} \mathrm{C}$.

\section{Conclusion}

Extender composition, temperature, freezing protocol, container and individual freezing affect spermatozoa viability. In our conditions, the LDL extender guarantees higher cell viability with less physical damages than Triladyl or Biociphos. This extender could be used advantageously for storage for short durations and for freezing of spermatozoa.

\section{Acknowledgements}

The authors express their thanks to Bernadette Delaleu and Chantal Thorin for their technical skills. The authors declare that there is no conflict of interest that would affect the impartiality of this scientific work.

\section{References}

Ahmad K \& Foote RH 1986 Post thaw survival and fertility of frozen bull spermatozoa treated with antibiotics and detergent. Journal of Dairy Science 69 535-541.

Amirat L, Tainturier D, Jeanneau L, Thorin C, Gérard O, Courtens JL \& Anton M 2004 Bull semen in vitro fertility after cryopreservation using egg yolk LDL: a comparison with Optidyl ${ }^{\circledR}$, a commercial egg yolk extender. Theriogenology 61 895-907.

Bogart R \& Mayer DT 1950 The effects of egg yolk on the various physical and chemical factors detrimental to spermatozoa viability. Journal of Animal Science 9143.

Bousseau S, Brillard JP, Marquant-Le Guienne B, Guerin B, Camus A \& Lechat M 1998 Comparison of bacteriological qualities of various egg yolk sources and the in vitro and in vivo fertilizing potential of bovine semen frozen in egg yolk or lecithin based diluents. Theriogenology 50 699-706.

Courtens JL \& Réty JM 2001 Numerical simulation for freezing and thawing mammalian spermatozoa. Evaluation of cell injuries at different depth in bags or straws during all steps of the technique. Genetic Selection Evolution 33 (Suppl 1) 85-104.

Courtens JL, Nunes JS \& Cortell JM 1984 Induction of the acrosome reaction in the spermatozoa of the goat by secretions of the male accessory glands and milk. Gamete Research 9 287-302.

Courtens JL, Ekwall H, Paquignon M \& Plöen L 1989 Preliminary study of water and some element contents in boar spermatozoa, before, during and after freezing. Journal of Reproduction and Fertility 87 613-626.

Demianowicz W \& Strezek J 1996 The effect of lipoprotein fraction of egg yolk on some of the biological properties of boar spermatozoa during storage of the semen in liquid state. Reproduction in Domestic Animals 31 279-280. 
Foulkes JA 1977 The separation of lipoprotein from egg yolk and their effect on the motility and integrity of bovine spermatozoa. Journal of Reproduction and Fertility 49 277-284.

Gil J, Januskauskas A, Haard MCh, Haard MGM, Johanisson A, Soderquist L \& Rodriguez-Martinez H 2000 Functional sperm parameters and fertility of bull semen extended in Biociphos Plus ${ }^{\circledR}$ and Triladyl ${ }^{\circledR}$. Reproduction in Domestic Animals 35 69-77.

Handbook of Chemistry and Physics 1990 edn 70, p D291. Eds RC West, DR Lide, MJ Astle \& WH Beyer. Boca Raton, FL: CRC Press.

Kampshmidt RF, Mayer DT \& Herman HA 1953 Lipid and lipoprotein constituents of egg yolk in the resistance and storage of bull spermatozoa. Journal of Dairy Science 36 733-742.

Lasley JF, Easly GT \& Bogart R 1942 Some factors influencing the resistance of bull sperm to unfavorable environmental conditions. Journal of Animal Science 179 (Abstract).

Moussa M, Martinet V, Trimeche A, Tainturier D \& Anton M 2002 Low density lipoproteins extracted from hen egg yolk by an easy method: cryoprotective effect on frozen- thawed bull semen. Theriogenology 57 1695-1706.

Pace MM \& Graham EF 1974 Components in egg yolk which protect bovine spermatozoa during freezing. Journal of Animal Science 39 1144-1149.

Phillips PH 1939 The preservation of bull semen. Journal of Biological Chemistry 130415.
Polge C \& Rowson LEA 1952 Results with bull semen stored at $-79^{\circ} \mathrm{C}$. Veterinary Record 64 851-854.

Quinn PJ \& Chow PYW 1980 Evidence that phospholipids protect spermatozoa from cold shock at a plasma membrane site. Journal of Reproduction and Fertility 60 403-407.

Van Wagtendonk-de Leeuw AM, Haring RM, Kaal-Lansbergen LMTE \& Den Daas JHG 2000 Fertility results using bovine semen cryopreserved with extenders based on egg yolk and soybean extract. Theriogenology 54 57-67.

Vishwanath R \& Shannon P 2000 Storage of bovine semen in liquid and frozen state. Animal Reproduction Science 62 (issues 1-3) $23-53$.

Wall RJ \& Foote RH 1999 Fertility of bull semen frozen and store in clarified egg yolk-Tris-glycerol extender. Journal of Dairy Science 82 817-821.

Watson PF \& Martin CA 1975 The influence of some fractions of egg yolk on the survival of ram spermatozoa at $5^{\circ} \mathrm{C}$. Australian Journal of Biological Science $\mathbf{2 8} 145-152$.

Received 16 September 2003

First decision 28 November 2003

Accepted 10 May 2004 